\title{
Enhanced Prokaryotic Expression of Dengue Virus Envelope Protein
}

\author{
Advaita Ganguly, Ravindra B. Malabadi, Dipankar Das, Mavanur R. Suresh and Hoon H Sunwoo \\ Faculty of Pharmacy and Pharmaceutical Sciences, University of Alberta, Edmonton, Alberta, Canada. \\ Received, April 18, 2013; Revised, July 4, 2013; Accepted, August 27, 2013; Published, October 13, 2013.
}

\begin{abstract}
Purpose. To highlight the expression and purification of the recombinant dengue virus type-1 antigen exploiting the codon optimized full length envelope for increased yield in E. coli. Methods. A 6x His tag was inserted at the $\mathrm{C}$ terminus to facilitate purification. The purified protein was recognized in Western blot by Monoclonal antibody specific for the tag. The in vitro refolded recombinant protein was used to immunize mice for the development of hybridomas and also analyzed for its biological functionality with heparan sulfate binding assay. Results. The polyclonal anti-sera from the immunized mice were found to recognize the envelope protein thereby establishing the immunogenicity of the protein. Conclusion. The purified envelope protein could potentially be used towards dengue diagnostics and vaccine development efforts.
\end{abstract}

This article is open to POST-PUBLICATION REVIEW. Registered readers (see "For Readers") may comment by clicking on ABSTRACT on the issue's contents page.

\section{INTRODUCTION}

Dengue virus is the most important arthropod-borne human pathogen. The incidence of dengue fever epidemics has increased significantly over the last few decades, and it is estimated that up to 100 million cases occur annually. In addition, a severe form of the disease, dengue hemorrhagic fever (DHF), has emerged in the same period causing 500,000 cases worldwide each year $(1,50)$. There are four different but antigenically closely related serotypes of dengue virus (DEN-1, 2, 3 and 4), and it is believed that DHF may result from secondary infection by different virus serotypes, in a process known as antibody mediated disease enhancement (2). This feature has made vaccine development efforts against the dengue virus a difficult issue. Nevertheless, researchers around the world are exploring different approaches towards dengue vaccine development based on recombinant viral proteins expressed in different systems, inactivated viruses, conventional live attenuated viruses, antigen encoding plasmids and viral vectors encoding antigen genes (3).

The envelope (Env) protein of the dengue virus is the most studied antigen. Several studies confirm that the Env protein can be an effective vaccine candidate. Multiple strategies including subunit Env vaccines, DNA vaccines and attenuated viruses are being undertaken to develop a suitable vaccine for controlling the viral infection (4-7).

The dengue virus Env protein is around 50-55 $\mathrm{kDa}$ in size, with the $\mathrm{N}$ terminal corresponding to the ectodomain that is exposed on the virion surface. The $\mathrm{C}$ terminal constitutes the transmembrane hydrophobic domain and helps anchor the molecule on the lipid bilayer. The envelope is a multifunctional protein with important roles in host cell surface receptor binding (8). The Env protein is also very important from the viewpoint of humoral immunity against the virus (9). Hence, efforts are made to express the Env protein in heterologous systems in order to develop it as a vaccine candidate.

The goal of this study was efficient cloning and expression of DEN-1 full length Env gene in E. coli that could be used to develop monoclonal antibodies (MAbs) by hybridoma technology or as a viable antigen for diagnostic and vaccine purposes. In this study, we report the successful cloning and high-level expression of the Env gene, purification from $E$. coli as inclusion bodies and its subsequent refolding. After purification with an affinity column and subsequent refolding, the protein was tested for its capability to induce robust humoral immune response in mice and virus blocking capability. The functionality of the refolded protein was further determined with heparan sulfate binding assay. Dengue virus infectivity has been reported to be dependent on the Env protein binding to heparan sulfate in the target cell (10).

Corresponding Author: Hoon H Sunwoo, Faculty of Pharmacy and Pharmaceutical Sciences, University of Alberta, 11304-89 Avenue, Edmonton, Alberta, Canada; E-mail: hsunwoo@ualberta.ca 
The recombinant antigen has been evaluated as a diagnostic reagent. This article illustrates enhanced expression and functionality of the recombinant protein.

\section{MATERIALS AND METHODS}

\section{Vector and Chemicals}

Restriction enzymes were procured from New England Biolabs (Mississauga, Canada). The antiHis 6 was purchased from Novagen Inc (Madison, USA). $40 \%$ acrylamide: bisacrylamide, prestained low range protein molecular weight markers and protein assay reagents were obtained from Bio-Rad (Mississuaga, Canada). Hybond ECL nitrocellulose membrane, X-ray film and the ECL Western blotting reagents were obtained from Amersham Pharmacia Biotech (Baied Urfe, Quebec, Canada). Glutathione (GSH) and Glutathione disulphide (GSSG) were purchased from Boehringer Mannheim. Baby Hamster Kidney (BHK 21) cells, C6/36 mosquito cells were obtained from American Type Culture Collection (Virginia, USA), Dengue-1 virus (Hawaii strain) was maintained in the C6/36 cells. Briefly, monolayers of $\mathrm{C} 6 / 36$ were incubated with virus at a multiplicity of infection of 0.01 and incubated at $26^{\circ} \mathrm{C}$ in $5 \% \mathrm{CO}_{2}$ for 5 days, Heparan sulfate, sodium deoxycholate, arginine, Goat anti Mouse-HRPO (GAM-HRPO), urea and other general reagents were obtained from Sigma (Oakville, Canada). Ni-NTA agarose, plasmid DNA isolation kit and gel extraction kit were obtained from Qiagen (Mississauga, Canada).

\section{Construction of Plasmid (pDS20Env)}

Codon optimized Env nucleotide sequence for $E$. coli expression was chemically synthesized from GENEART, Germany. The codon optimized Env gene comprising of the plasmid and the expression vector pBM802 were NdeI and EcoRI digested followed by gel purification and ligation. The ligation mixtures were subsequently transformed in E. coli Rosetta (ATCC 87064, E. coli DE3) by a heat shock method for recombinant protein expression. Screening of the resultant transformants was done by plasmid DNA isolation and restriction digestion (11).

\section{Analysis of recombinant clones}

Individual bacterial colonies were grown in $2 \mathrm{~mL}$ Terrific Broth (TB) medium (1.2\% tryptone, 2.4\% yeast extract, $0.4 \%(\mathrm{v} / \mathrm{v})$ glycerol and $25 \mathrm{mM}$ Hepes
$\mathrm{pH}$ 7.2) comprising tetracycline and chloramphenicol, $5 \mu \mathrm{gmL}^{-1}$ and $34 \mu \mathrm{gmL}^{-1}$, respectively, followed by overnight incubation at $37^{\circ} \mathrm{C}$ with shaking at $250 \mathrm{rpm}$. The culture was diluted 100 fold the next day in fresh TB medium comprising 5 $\mu \mathrm{gmL}^{-1}$ tetracycline and $34 \mu \mathrm{gmL}^{-1}$ chloramphenicol and grown at $37^{\circ} \mathrm{C}$ with brisk shaking at $250 \mathrm{rpm}$. The bacterial culture was induced with $0.2 \%(\mathrm{w} / \mathrm{v})$ of arabinose on reaching optical density $\left(\mathrm{OD}_{600 \mathrm{~nm}}\right)$ of approximately $0.5-0.6$ and was thereafter allowed to grow overnight $(\sim 16$ h) at $37^{\circ} \mathrm{C}$ with shaking at $250 \mathrm{rpm}$. The bacterial culture was harvested by centrifugation at $5,000 \mathrm{x} \mathrm{g}$ for $10 \mathrm{~min}$ at $4^{\circ} \mathrm{C}$ and the total cell protein lysate was prepared (12). The total cell protein was analyzed by SDS-PAGE using $10 \%$ polyacrylamide gel, according to Laemmli's method (13) and stained.

\section{Expression optimization (Temperature, Time and Inducer)}

The Env protein expression was optimized for three different sets of temperatures $\left(37^{\circ} \mathrm{C}, 30^{\circ} \mathrm{C}\right.$ and $24^{\circ} \mathrm{C}$ ), varied time durations and inducer (arabinose) concentrations. Bacterial growth conditions were identical as defined earlier. The bacterial culture was induced with $0.2 \%(\mathrm{w} / \mathrm{v})$ of arabinose at optical density $\left(\mathrm{OD}_{600 \mathrm{~nm}}\right)$ of $0.5-0.6$ and allowed to grow overnight $(\sim 16 \mathrm{~h})$ at three different temperatures. For time optimization, the bacterial culture was induced with $0.2 \%(\mathrm{w} / \mathrm{v})$ of arabinose after an absorbance of 0.5 was reached. The cultures were further allowed to grow for $0 \mathrm{~h}, 2$ $\mathrm{h}, 4 \mathrm{~h}, 6 \mathrm{~h}$ and overnight $(\sim 16 \mathrm{~h})$ at $37^{\circ} \mathrm{C}$. The bacterial cultures were induced with different concentrations of arabinose $(2 \%, 0.2 \%, 0.02 \%$, $0.002 \%$ and $0.0002 \%$ ) and allowed to grow over night $(\sim 16 \mathrm{~h})$ at $37^{\circ} \mathrm{C}$. The total cell proteins obtained from each experiment were analyzed by SDS- PAGE and Western blot.

\section{Medium scale expression and purification of the viral antigen}

A fresh single colony of E. coli transformants containing pDS20Env was inoculated in $10 \mathrm{~mL}$ TB medium containing $5 \mu \mathrm{gmL}^{-1}$ of tetracycline and 34 $\mu \mathrm{gmL}^{-1}$ chloramphenicol and allowed to grow overnight at $37^{\circ} \mathrm{C}$ in an incubator shaker at 250 $\mathrm{rpm}$. The overnight culture was diluted 100 times in $1 \mathrm{~L}$ TB medium containing $5 \mu \mathrm{gmL}^{-1}$ of tetracycline and $34 \mu \mathrm{gmL}^{-1}$ chloramphenicol and grown at $37^{\circ} \mathrm{C}$ with shaking at $250 \mathrm{RPM}$ until an 
$\mathrm{OD}_{600 \mathrm{~nm}}$ of $0.5-0.6$ was reached. Induction was done by arabinose addition to a final concentration of $0.2 \%(\mathrm{w} / \mathrm{v})$ and bacterial culture was incubated for $16 \mathrm{~h}$ with vigorous shaking $(250 \mathrm{rpm})$ at $37^{\circ} \mathrm{C}$. Pellets were collected by centrifugation at $5,000 \mathrm{X}$ $\mathrm{g}$ for $20 \mathrm{~min}$ at $4^{\circ} \mathrm{C}$. Total cell proteins from both uninduced and induced culture were analyzed by SDS-PAGE and Western blot.

\section{Processing of inclusion bodies}

The bacterial pellet ( $3 \mathrm{~g}$ ) was resuspended in $30 \mathrm{~mL}$ PBS and lysed by French Press (20,000 psi). The cell lysate was clarified by centrifugation at 27,000 $\mathrm{X} g$ for $30 \mathrm{~min}$ at $4^{\circ} \mathrm{C}$ and the supernatant was discarded. The pellet was again resuspended in 50 $\mathrm{mL}$ lysis buffer (50 mM Tris, $\mathrm{pH} 8.0,200 \mathrm{mM}$ $\mathrm{NaCl}$ and $1 \mathrm{mM}$ EDTA) and adjusted to $2 \%$ sodium deoxycholate, incubated at room temperature for $30 \mathrm{~min}$ and centrifuged at $27,000 \mathrm{X} \mathrm{g}$ for $30 \mathrm{~min}$ at $4^{\circ} \mathrm{C}$. The pellet was resuspended in lysis buffer and washed three times at $27,000 \mathrm{X} \mathrm{g}$ for $20 \mathrm{~min}$ at $4^{\circ} \mathrm{C}$.

\section{Protein purification (IMAC) under denaturing conditions}

Inclusion bodies from the above step were solubilized in denaturing buffer $(8 \mathrm{M}$ urea, $100 \mathrm{mM}$ $\mathrm{NaH}_{2} \mathrm{PO}_{4}, 10 \mathrm{mM}$ Tris-HCl, $\mathrm{pH}$ 8.0) for $1 \mathrm{~h}$ at room temperature with occasional shaking. Solubilized proteins were separated from insoluble material by centrifugation at $27,000 \mathrm{Xg}$ for $30 \mathrm{~min}$ at $4{ }^{\circ} \mathrm{C}$ and the final yield of solubilized protein was determined by Bradford assay. An IMAC based separation system was prepared by loading $9 \mathrm{~mL}$ of Ni-NTA agarose on a column. The column was equilibrated with 5 bed volumes of denaturing buffer $(8 \mathrm{M}$ urea, $100 \mathrm{mM} \mathrm{NaH}_{2} \mathrm{PO}_{4}, 10 \mathrm{mM}$ Tris- $\mathrm{HCl}, \mathrm{pH}$ 8). Denatured soluble protein was loaded on the column and the column was washed initially with 5 bed volumes of washing buffer $(8 \mathrm{M}$ urea, $100 \mathrm{mM}$ $\mathrm{NaH}_{2} \mathrm{PO}_{4}, 10 \mathrm{mM}$ Tris-HCl, $\mathrm{pH}$ 6.3). Bound protein was eluted with elution buffer $(8 \mathrm{M}$ urea, $100 \mathrm{mM}$ $\mathrm{NaH}_{2} \mathrm{PO}_{4}, 10 \mathrm{mM}$ Tris-HCl, $\mathrm{pH}$ 4.5). The various eluted fractions were analyzed by SDS-PAGE to measure the purity.

\section{Refolding}

Protein assay was done by Bradford method to quantify the amount of eluted protein from the IMAC column. The eluted protein was diluted to $75 \mu \mathrm{gmL}^{-1}$ and $60 \mu \mathrm{gmL}^{-1}$ with Tris Arginine (TA) dialysis buffer $(50 \mathrm{mM}$ Tris, $\mathrm{pH} 8.0,0.4 \mathrm{M} \mathrm{L}$ arginine) to identify the appropriate refolding condition. Refolding was done by dialysis in TA buffer in the presence of $1.0 \mathrm{mM} \mathrm{GSH}$ and $0.1 \mathrm{mM}$ GSSG, and changed three times over three days at $4^{\circ} \mathrm{C}$. Final dialysis was done in PBS at $4^{\circ} \mathrm{C}$. Any aggregation was removed by centrifugation and the supernatant was collected as a soluble refolded protein.

\section{Western blot analysis}

Total cell proteins, inclusion bodies, IMAC eluted fractions or refolded Env proteins were separated on SDS-PAGE using 10\% polyacrylamide gel and transferred onto hybond ECL nitrocellulose membranes [14] with a transblot apparatus (BioRad) according to the manufacturer's instructions. The membrane was blocked with 5\% skim milk in PBST (0.1\% Tween 20 in PBS, pH 7.3) for $1 \mathrm{~h}$. The membrane was washed four times with PBST and incubated for $1 \mathrm{~h}$ with anti-His 6 MAb. After washing four times with PBST, the membrane was incubated with GAM-HRPO for $1 \mathrm{~h}$. Finally, the membrane was washed with PBST four times and ECL-based detection was performed according to manufacturer's instructions.

\section{In gel digestion}

Protein identification by LC-MS was performed at the Institute of Biomolecular design, University of Alberta, Edmonton, Alberta, Canada.

\section{Heparan Sulfate binding assay}

Refolded protein was analysed for recognition of heparan sulfate by ELISA. Briefly, 96-well Maxisorp plates were coated with $0.5 \mu \mathrm{gmL}^{-1}$ heparan sulfate and blocked with 3\% bovine serum albumin (BSA). Heparan sulfate coated wells were incubated with refolded protein for $1 \mathrm{~h}$ at $37^{\circ} \mathrm{C}$. Serial dilutions of refolded Env protein were analysed. Then, wells were washed four times with PBST and incubated with $100 \mu$ of diluted $(1: 1,000$ in $5 \% \mathrm{BSA}$ ) anti-His 6 MAb for $1 \mathrm{~h}$ at room temperature. The wells were washed again and incubated with anti-mouse IgG HRP (at 1:1,000 dilutions in $5 \% \mathrm{BSA}$ ) for $1 \mathrm{~h}$ at room temperature. The color reaction was developed with TMB. The optical density was measured at $650 \mathrm{~nm}$. Two negative controls (all assay components minus the recombinant protein and the other minus heparan sulfate) and a blank (containing only the detection reagents) were also included in the assay. The assay was repeated 3 times. 


\section{Immunization of mice}

Groups of five balb/c mice were intra-peritoneally injected with $25 \mu \mathrm{g}$ of purified Env protein in PBS emulsified with an adjuvant (protocol number 074/09/09, approved by Health Science Animal Protocol Committee, University of Alberta). The protein was administered to the mice on days 0,14 and 28 using Freund's complete adjuvant for the first administration and Freund's incomplete adjuvant for the second administration. The final injection was with $10 \mu \mathrm{g}$ of protein in PBS. Mice were bled one week after the last administration and serum samples were then collected for further analysis.

\section{Preparation of Dengue virus type 1 stock}

The culture supernatant, obtained from dengue 1 virus (Hawaii strain)-infected C6/36 culture after removal of cellular junk by centrifugation, was used as the source of virus. The stock was titrated on BHK cells grown in culture plates. The virus dilution at which $50 \%$ of the infected wells resulted in Cytopathic Effect was done by an established method (39) and viral titers were formulated as the reciprocal of the dilution in terms of Tissue Culture Infective Doses (TCID 50 ) (31).

\section{Virus binding blocking assay}

The ability of the Env protein to block dengue virus type 1 binding to cells in tissue culture was performed (31). BHK cells were immobilized in 96well plates $\left(2 \times 10^{3}\right.$ cells/well $)$. At about $60 \%$ confluency, they were pre-incubated for $30 \mathrm{~min}$ at $37^{\circ} \mathrm{C}$ with $200 \mu \mathrm{l}$ of $1 \times$ PBS containing either the test (Env) or control proteins. We used BSA as a control. Protein concentration in each case was from 0 to $20 \mu \mathrm{g}$ per well. Following pre-incubating with the proteins $50 \mu \mathrm{L}$ dilute Dengue type 1 virus (equivalent to $250 \mathrm{TCID}_{50}$ ) was added to each well and incubated for $30 \mathrm{~min}$ at $37^{\circ} \mathrm{C}$. After this, the protein/virus mixture was aspirated out the cells were washed three times with $1 \times$ PBS and fresh medium $(200 \mu \mathrm{L} /$ well $)$ was added followed by incubation for 3 days in a humidified $10 \% \mathrm{CO}_{2}$ incubator at $37^{\circ} \mathrm{C}$. After 3 days the wells were scored for the presence or absence of cytopathic effects (CPE) by microscopic examination.

\section{Envelope Protein as a diagnostic reagent}

We spiked different concentrations of anti-dengue monoclonal antibody $8 \mathrm{~A} 5$ in rabbit serum and neat serum was used as blank. We also used serum spiked with SARS antibodies as negative control. We blinded the tubes and labeled the samples 1-7 randomly. The purified full length Env protein was diluted to $10 \mu \mathrm{gmL}^{-1}$ in $0.1 \mathrm{M}$ bicarbonate buffer (pH 9.6) and 96-well Maxisorp plates were coated overnight at $4^{\circ} \mathrm{C}$. The coated plates were washed with PBS and blocked with 2\% BSA for $2 \mathrm{~h}$ at $37^{\circ} \mathrm{C}$. The plates were washed again with PBS. 100 $\mu \mathrm{L}$ of the samples were added to the wells and incubated for $2 \mathrm{~h}$ at $37^{\circ} \mathrm{C}$. The plates were washed again with PBS and anti-mouse IgG conjugated to Horseradish peroxidase was added (1:10000 dilution) for $30 \mathrm{~min}$ at $37^{\circ} \mathrm{C}$. The plates were washed again with PBS and TMB substrate added and absorbance was read at $650 \mathrm{~nm}$. The assay was done in triplicates.

\section{Evaluation of assay with clinical samples}

Clinical samples from dengue infected patients being difficult to procure, we simulated the assay with 21 human serum samples collected from TB patients at diagnosis prior to initiating drug therapy who were part of a cohort of newly diagnosed TB patients from the Tuberculosis Trials Consortium Study Group 22 between 1995 and 1998 (48, 49). Anti dengue mAb was spiked in the samples in different concentrations. Non-spiked samples were used as control. 96-well plates were coated overnight at $4^{\circ} \mathrm{C}$ with full length Env protein diluted to $10 \mu \mathrm{gmL}^{-1}$ in $0.1 \mathrm{M}$ bicarbonate buffer ( $\mathrm{pH}$ 9.6). The plates were then washed with PBS and blocked with $2 \%$ BSA for $2 \mathrm{~h}$ at $37^{\circ} \mathrm{C}$. The plates were washed again with PBS. $100 \mu \mathrm{L}$ of the samples were added to the wells and incubated for 2 $\mathrm{h}$ at $37^{\circ} \mathrm{C}$. The plates were washed again with PBS and anti-mouse IgG conjugated to Horseradish peroxidase was added (1:10000 dilution) for $30 \mathrm{~min}$ at $37^{\circ} \mathrm{C}$. The plates were washed again with PBS and TMB substrate added and absorbance was read at $650 \mathrm{~nm}$. The assay was done in triplicates.

\section{RESULTS}

\section{Env gene cloning and expression}

The full length Env gene was successfully cloned with the C-terminal $\mathrm{His}_{6}$ tag and denoted as pDS20Env for higher expression of proteins in $E$. coli in the form of inclusion bodies (15). Recombinant clones pertaining to the right size were selected for protein expression. The full length Env gene comprising plasmid was isolated for expression. Expression results of various clones 
showed that all the Env full length clones selected expressed the protein of interest at approximately $54 \mathrm{kDa}$ at varying levels as determined by SDSPAGE analysis (data not shown). This was confirmed by Western blot probed with anti-His 6 $\mathrm{MAb}$ (Figure 1). In the control sample, no expression of Env protein was observed. The best Env clone was selected for expression optimization and further studies.

\section{Expression optimization (Temperature, Time and Inducer)}

The Env protein was successfully expressed as a recombinant protein in E.coli. The optimal conditions for Env protein expression were $0.2 \%$ $(\mathrm{w} / \mathrm{v})$ arabinose concentration (Figure $2 \mathrm{a}$ and $2 \mathrm{~b}$ ), $37^{\circ} \mathrm{C}$ temperature (Figure $3 \mathrm{a}$ and $3 \mathrm{~b}$ ) and $16 \mathrm{~h}$ induction time (Figure 4).

\section{Medium scale expression of Env protein}

The recombinant Env was expressed and the bulk of the antigen was in the inclusion bodies (Figure 5). Inclusion bodies were prepared from bacterial pellet by French press. After completion of cell lysis, the insoluble inclusion bodies were separated from the soluble bacterial protein by centrifugation and thereafter the pellets were washed with sodium deoxycholate. Any remaining sodium deoxycholate were removed from the inclusion bodies by subsequent washes with lysis buffer. The purity of the inclusion bodies along with the different washes was analyzed by SDS-PAGE (data not shown). The final yield of purified soluble inclusion bodies was estimated by Bradford protein assay to be approximately $15-20 \mu \mathrm{gmL}^{-1}$ of bacterial culture.

\section{Purification and Refolding}

The insoluble protein was isolated from inclusion bodies with a final purified protein yield in the range of $15-20 \mathrm{mgL}^{-1}$ of bacterial shake flask culture and purified by immobilized metal-affinity chromatography (IMAC) under denaturing conditions. The purification method involved IMAC for separating recombinant proteins from major bacterial contaminants. Employing this method, pure proteins were eluted out from the IMAC affinity column as determinated in the methods section. The eluted protein showed a single band of approximate molecular weight of $54 \mathrm{kDa}$, with purity greater than $90 \%$ (Figure 6). Folding of proteins and disulphide bond formation and association of various domains require renaturing conditions and suitable buffers. The presence of arginine in the refolding buffer helped in solubilization, inhibiting aggregation of refolding intermediates and thereby increasing the yield (16). Refolding was done over three days by dialysis. No aggregation was observed after refolding. The supernatant was collected as refolded Env protein for future use. Hence, the in vitro refolding was successful in recovering the soluble protein expressed in E.coli in form of inclusion bodies.

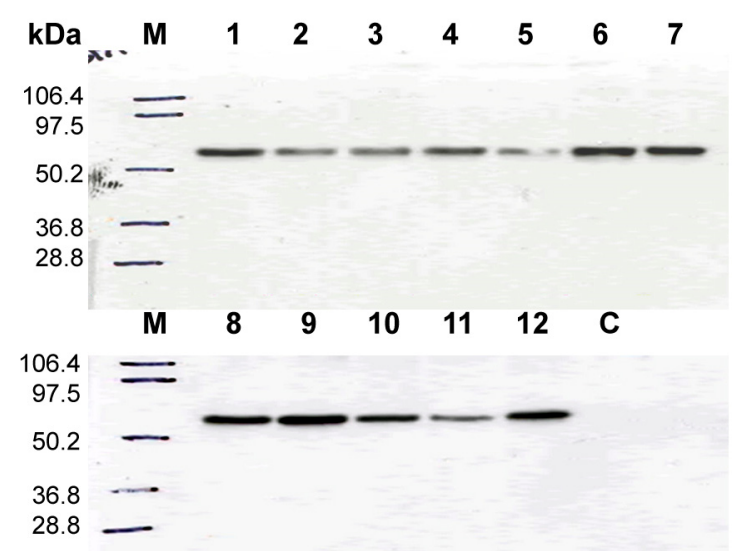

Figure 1. Envelope protein expression. Lane M: Marker, Lanes 1-12: Clones \# 1-12 and Lane C is Control.

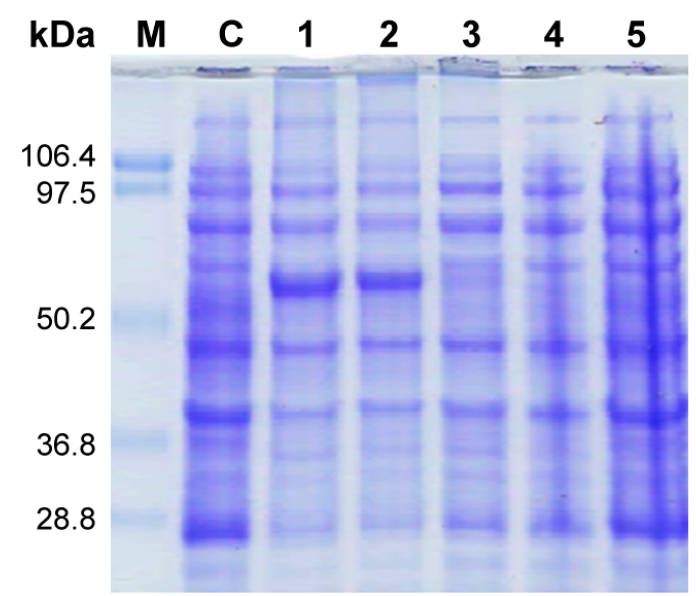

Figure 2a. Arabinose dose optimization of envelope protein expression a SDS-PAGE. Lane M: prestained marker, Lane C: Control, Lanes 1-5: 2\%, 0.2\%, 0.02\%, $0.002 \%, 0.0002 \%$. 


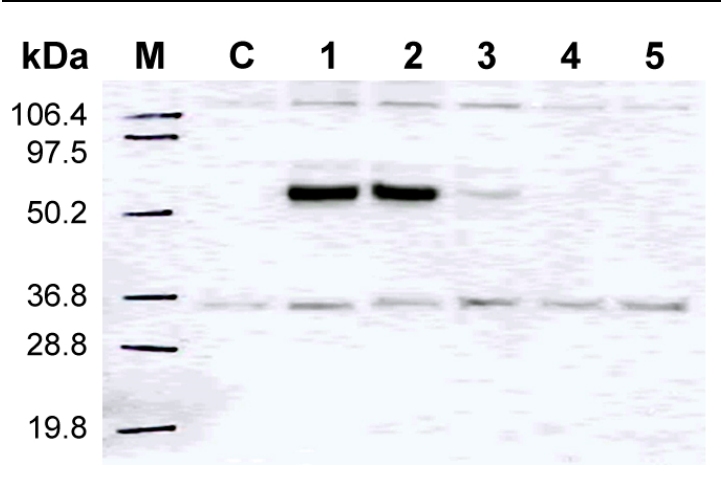

Figure 2b. Western blot. Lane M: prestained marker, Lane C: Control, Lanes 1-5: $2 \%, 0.2 \%, 0.02 \%, 0.002 \%$, $0.0002 \%$.

\section{In Gel Digestion}

Non-redundant National Center for Biotechnology Information (NCBI) database was searched for protein identification from the LC/MS data according to established protocol (11). Significant hits were obtained from the search for the DEN- 1 polyprotein which included Env (gi)130423 polyprotein (Dengue virus type 1).

\section{Immunogenicity of the purified Env protein}

Mice were immunized intra peritoneally $(60 \mu \mathrm{g}$ at two week intervals) Sera from immunized mice were analyzed by ELISA (Figure 7) and Western blot (Figure 8). The results indicate development of robust humoral immunity in mice. Immunized mice sera could also bind to the purified and refolded dengue Env protein on Western blot.

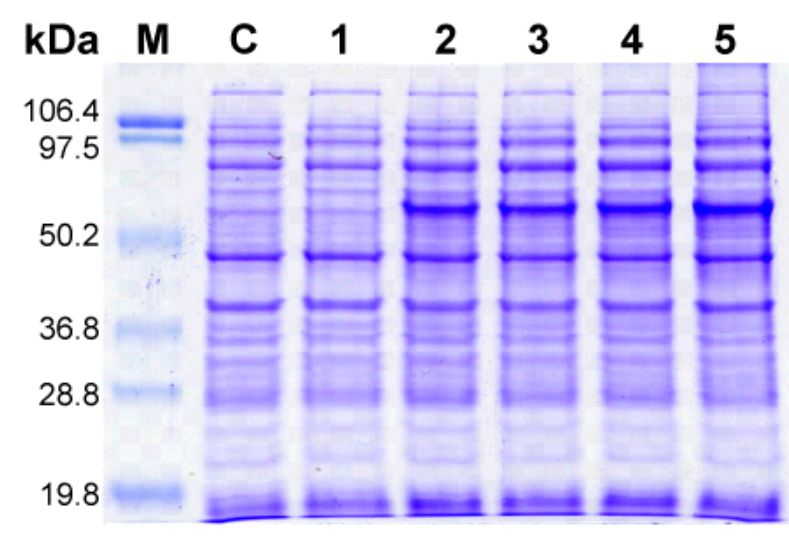

Figure 3a. Time induction of envelope protein expression a SDS-PAGE. Lane M: prestained marker, Lane C: Control, Lanes 1-5: 0 h, 2 h, 4 h, 6 h, Overnight.

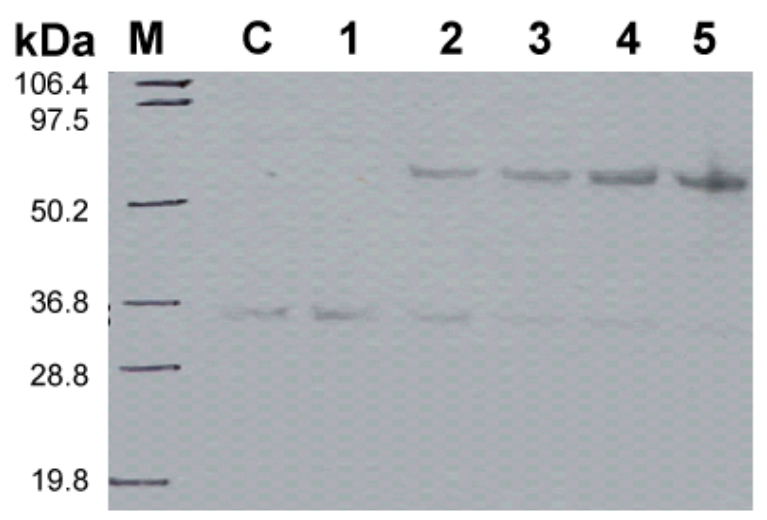

Figure 3b. Western blot. Lane M: prestained marker, Lane C: Control, Lanes 1-5: 0 h, 2 h, 4 h, 6 h, Overnight.

\section{Refolded Env protein neutralizes Dengue virus - 1 infection}

After refolding, the recombinant protein's biological functionality was assessed by virus blocking assay. Pre-incubated BHK cells with various concentrations of refolded Env protein were infected with Dengue type 1 virus. Total blocking was observed at concentrations $16 \mu \mathrm{g}$ and higher (Figure 10). This substantiates a successful refolding of the recombinant protein and its potential as a vaccine candidate for its ability to neutralize virus infection.

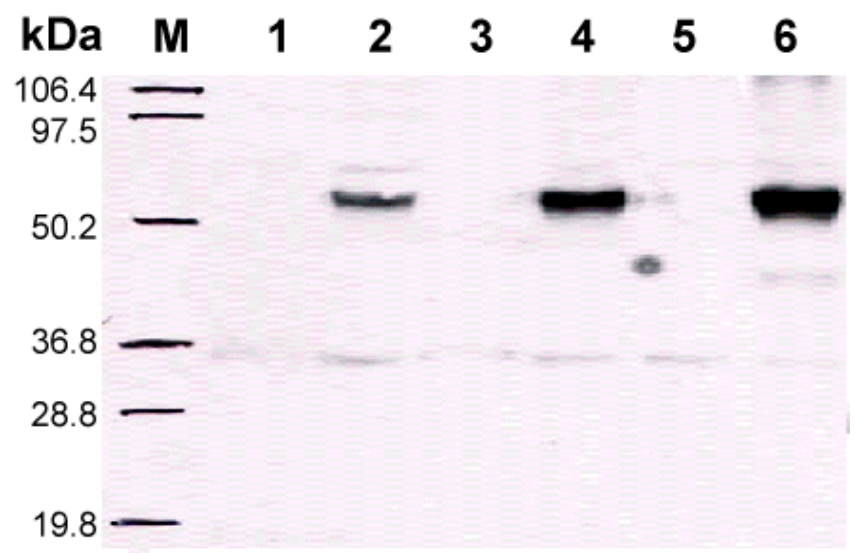

Figure 4. Temperature optimization of envelope protein expression by Western blot. Lane M: prestained marker Lane 1: $24^{\circ} \mathrm{C}$ Control, Lane 2: $24^{\circ} \mathrm{C}$ Test, Lane 3: $30^{\circ} \mathrm{C}$ Control, Lane $4: 30^{\circ} \mathrm{C}$ Test, Lane $5: 37^{\circ} \mathrm{C}$ Control, Lane 6: $37^{\circ} \mathrm{C}$ Test.

\section{Binding Assay}

The recombinant protein was found to be biologically functional based on the heparan sulfate 
binding assay (Figure 9). Denatured protein was also analyzed in a parallel assay (data not shown) wherein the binding was not as significant as previously reported by pattnaik and co-workers (17).

\section{Diagnostic evaluation of anti-dengue antibodies using recombinant antigen}

The recombinant env protein was used in indirect ELISA for detection anti dengue antibodies in the blinded spiked samples. We tested 5 samples with varying dengue antibody concentrations along with blank and negative control. The assay could positively detect the 5 samples that had spiked dengue antibodies and the remaining two samples yielded negative result. The specificity of the ELISA was found to be $100 \%$ (Table 2).

\section{Simulation of diagnostic immunoassay with clinical samples}

The Env antigen was also evaluated in an indirect immunoassay to detect anti dengue Envelope antibodies spiked in clinical samples. The assay was able to successfully detect antibodies in the nanogram range. Control sample that were not spiked with dengue antibodies gave negative result.

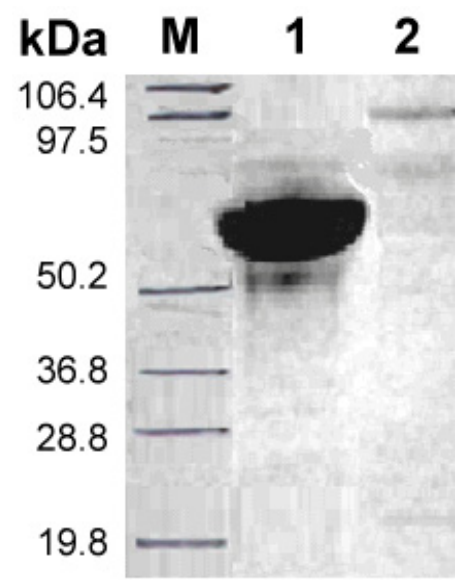

Figure 5. Accumulation of envelope protein in inclusion bodies (Lane 1) and soluble fractions (Lane 2) by Western blot. M: prestained marker.

\section{DISCUSSION}

The Env protein of Dengue viruses is widely recognized as a major subunit vaccine component. The Env protein is a multifunctional protein with proven roles in host cell surface receptor binding
(18). It is also one of the important targets to induce protective and prolonged immune response [19].

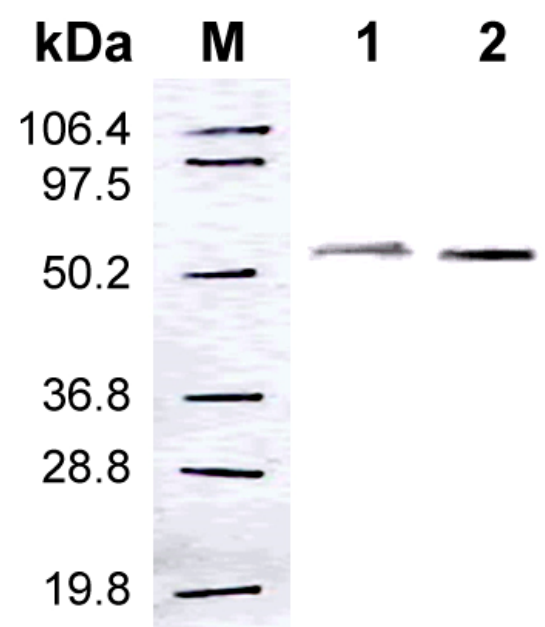

Figure 6. Refolded envelope protein by Western blot. Lane M: prestained marker, Lane 1: refolded envelope protein $\left(75 \mu \mathrm{gmL}^{-1}\right)$, Lane 2 : envelope protein $(60 \mu$ $\left.\mathrm{gmL}^{-1}\right)$.

The dengue envelope comprises of three structurally distinct domains: I, II and III. Domain III is known to have a role in host cell receptor binding for viral attachment and also in inducing protective antibodies against dengue virus infection in mice $(17,19)$. This dengue Envelope protein is therefore considered an important antigen for vaccine development and use as a reagent for diagnostic purposes $(24,25,42,43)$. Earlier studies have used different expression systems involving yeast, insect cells and $E$ coli for Env expression (20-22). In most of the previous expression systems and purification methods the recombinant proteins were associated with fusion tags such as glutathione S-transferase (GST) and maltose binding proteins for expressing the protein in soluble form with subsequent affinity purification (23). Most studies show that yields of the Dengue Env protein to be low associated with significantly high cost of production. Low expression levels and difficulty in purification has been a major hindrance in the development of Env based subunit vaccines (24). The baculovirus based expression of the antigen has been reported to form aggregates (25). The Env glycoprotein is also very important for vaccine and therapeutic aspects due to the presence of neutralizing epitopes (26-27). 


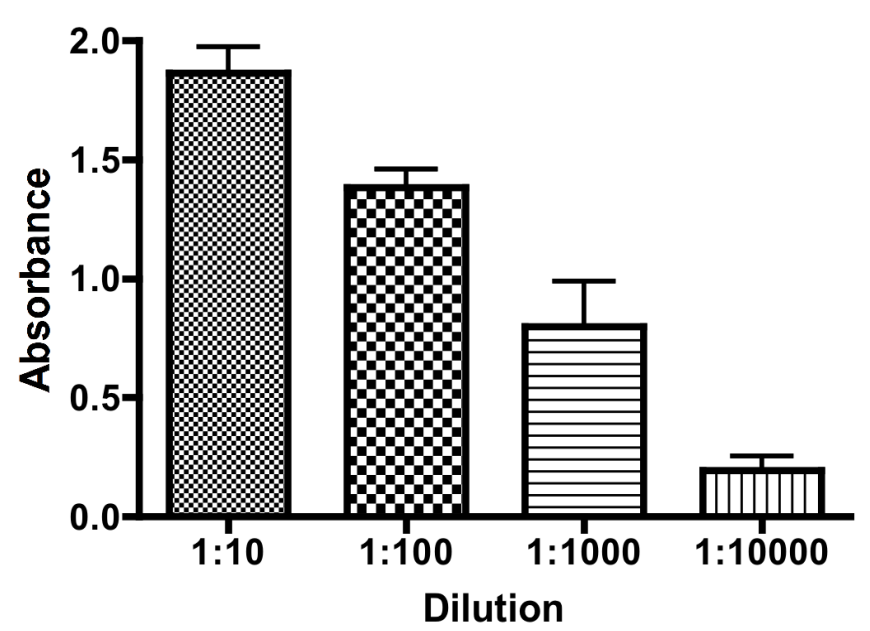

Figure 7. Indirect ELISA of mice sera immunized by Dengue envelope protein at absorbance of $650 \mathrm{~nm}$. Analysis of humoral immune response to dengue envelope protein.

In the present study we have used the E coli system for the production of Env protein, which is one of the most frequently used for recombinant protein expression. An advantage of the $E$. coli system is its convenient expression capability and low cost. It is known that E. coli expressed eukaryotic protein folding is difficult to obtain as a soluble protein.

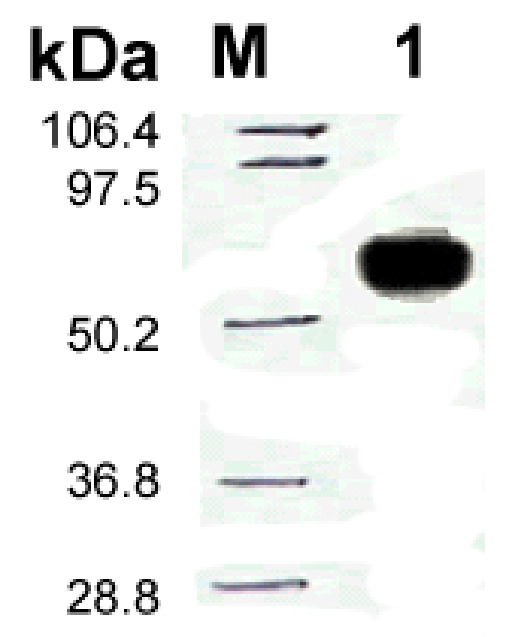

\section{8}

Figure 8. Western blot analysis of refolded envelope protein probed with mouse anti-Env polyclonal antibodies. Lane M: prestained marker, Lane 1: refolded envelope protein.

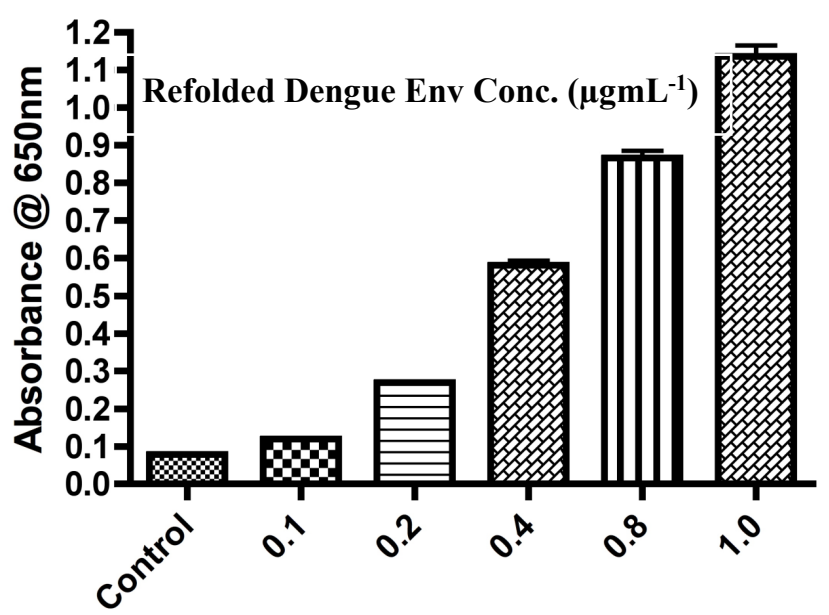

Figure 9. Receptor binding assay with purified and refolded Dengue envelope protein. ELISA plate wells were coated with $0.5 \mu \mathrm{gmL}^{-1}$ cell free soluble heparin sulfate, except the control wells. Different concentrations of refolded protein were used. Refolded protein bound to heparin sulfate in a concentration dependent manner.

Large-scale expression of proteins is conducible to precipitation thereby forming inclusion bodies [28-29]. Protein purification from inclusion bodies gives a better yield and is relatively simple to purify as previously demonstrated in our laboratory. Earlier studies show that codon optimized genes boost expression level than the native gene (28).

In this study, we have obtained codon optimized Env gene chemically for expression in $E$. coli. Codon optimization substantially enhances

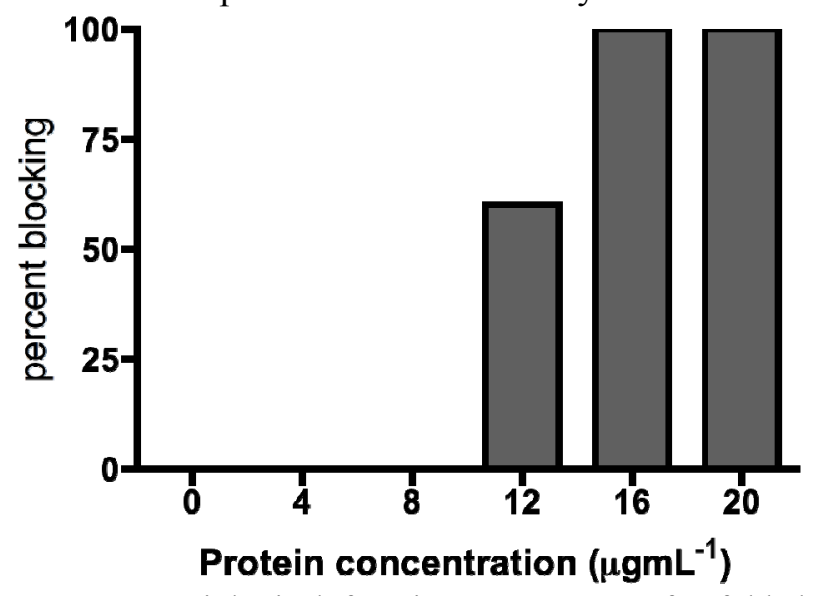

Figure 10. Biological function assessment of refolded Env protein. BHK cells were pre-incubated with various concentrations of Env protein and BSA (control) and then infected with dengue virus type $1\left(250 \mathrm{TCID}_{50}\right.$ per well). Afetr 3 days, the wells were examined under a microscope for cytopathic effects. Three wells were examined for each concentration. 
gene expression that leads to higer level of protein expression. Codon optimization was carried out using optimizer software in Geneart. They follow a deterministic sliding window algorithm for multiparameter sequence optimization. The target sequences are determined with a quality attribute taking codon usage, GC content, mRNA structure and species-specific sequence motifs into consideration. The first codon of the best candidates' variation window is made absolute and the window is shifted by one codon position towards the 3' end (30). We have cloned and purified the Dengue Env in E. coli for the development of MAbs for primarily translational applications. The Env protein could also be used for dengue detection and therapeutic and vaccine applications. The 6x His tag was inserted at the Cterminal end of the recombinant protein to augment easy purification. This tag has negligible immunogenicity and hence need not be removed from the recombinant protein (31). We also analyzed a range of conditions to validate the optimal temperature, time and inducer concentration for highest protein expression (11).

The Env gene was cloned in presence of a promoter for high-level expression of recombinant protein as inclusion bodies. The pBM802 vector was used for cloning under the control of the pBAD promoter that is nothing but arabinose promoter hence arabinose was used as inducer (32). This promotes high level expression of recombinant protein as inclusion bodies in the bacterial cytoplasm. The final yield of purified inclusion bodies was estimated by Bradford protein assay (33) and estimated to be approximately $15-20 \mathrm{mgL}^{-1}$ (Table 1) of initial bacterial culture which is $5-10$ fold higher compared to previous studies using the native $\mathrm{E}$ gene sequence $(19,22,31)$. The purity of inclusion bodies was determined by SDS-PAGE and Western blot. French Press lysis of cells and subsequent washing steps with detergent were adopted to purify the inclusion bodies from soluble proteins. SDS-PAGE analysis (data not shown) demonstrated that lysis by French Press and further washing with PBS substantially enhanced the purity of the inclusion bodies as a large amount of the $E$. coli soluble proteins could be separated. The purification method comprising of IMAC under denaturing conditions adsorbed the His-tagged protein (23). IMAC purification under denaturing conditions produced better amounts of pure Env protein with one band as determined by SDS-PAGE analysis. Bradford assay estimated a final concentration of around $80 \%$ of the initial amount. Recombinant proteins are expressed in E. coli as inclusion bodies and various refolding methods have been described to renature the proteins from inclusion bodies (23).

The IMAC purified Env protein was refolded using TA buffer consisting of a redox pair (GSH/GSSG) with two different protein concentrations $\left(75 \mu \mathrm{gmL}^{-1}\right.$ and $\left.60 \mu \mathrm{gmL}^{-1}\right)$. No aggregation was visible with both the concentrations during the process of refolding. SDS-PAGE and Western blot analyses were used to determine the purity of the refolded protein. Anti$\mathrm{His}_{6} \mathrm{MAb}$ reacted with a single band of $\sim 54 \mathrm{kDa}$, suggesting a successful purification of recombinant Env. The identity of purified protein was further confirmed by in vitro gel digestion, mass spectrometry, and NCBI non-redundant database search which proved that the purified protein band to be the dengue polyprotein of our interest. The protein was also probed with dengue Env MAbs thus confirming proper refolding. The Env protein was also successful in inducing a robust humoral immune response in balb/c mice as evidence from the high antibody titers and western blot analysis. The refolded Env protein was used as an antigen to immunize mice for development of MAbs. The polyclonal antibodies from mice sera were strongly binding with the recombinant protein in Western blot (Figure 8). The conformation of the Env protein plays an important role during viral infection (34). We did not analyze the crystal structure of the recombinant Env protein but putting it in perspective to findings by various research groups we can predict our refolded protein to be having a postfusion conformation. It has been reported that exposure to detergent and acidic $\mathrm{pH}$ would lead to trimeric postfusion conformation (35). As our procedure involves similar parametric conditions we can anticipate the structural conformation. In addition anti dengue MAbs 8A5 and $12 \mathrm{~A} 1$ were sourced from our collaborators in the United States to probe our refolded Env protein in Western blot as well as standard ELISA and we found desired level of interaction (data not shown). Subsequent analysis of the functional integrity of the refolded protein was done by a dengue virusblocking assay. The assay demonstrated the ability of the recombinant Env protein to completely neutralize dengue virus infectivity. Cells in the presence of the recombinant protein were protected 
from Dengue type 1 virus challenge (Figure 10). It can be concluded that this could be the result of competition between the recombinant protein and the dengue type 1 virus for the host cell surface receptors. This phenomenon is consistent with the earlier findings of Jaiswal and associates (31).
The functionality of the recombinant protein was further analyzed with heparan sulfate based assay. The recombinant protein may also be used as a diagnostic antigen. Our blinded optimized diagnostic assay resulted in $100 \%$ specificity. The specificity and sensitivity of the assay was further established in the analysis with the clinical samples.

\begin{tabular}{llllc}
\hline \multicolumn{5}{l}{ Table 1. Comparative analysis of production of full length Env protein } \\
\hline Dengue Envelope Type & Affinity Tag & Host & Yield & Reference \\
\hline Dengue 1 Envelope & His 6 & E. coli & $15-20 \mathrm{mg} \mathrm{L}_{6}^{-1}$ & This article \\
Dengue 1 Envelope & GST & E. coli & $2 \mathrm{mg} \mathrm{L}^{-1}$ & {$[22]$} \\
Dengue 1 Envelope & GST & Pichia & $0.1 \mathrm{mg} \mathrm{L}^{-1}$ & {$[22]$} \\
Dengue 2 Envelope & HBsAg & Pichia & $0.5 \mathrm{mg} \mathrm{L}^{-1}$ & {$[38]$} \\
Dengue 2 Envelope & MBP & Sf9 & $1 \mathrm{mg} \mathrm{10}^{-9}$ cells & {$[21]$} \\
\hline
\end{tabular}

\begin{tabular}{ccc}
\hline \multicolumn{3}{c}{ Table 2. Range of $\mathrm{OD}_{650}$ values in blinded diagnostic assay } \\
\hline Range of OD value & Blinded Sample No & Original Sample \\
\hline $0.736-0.910$ & 1 & $8 \mathrm{ngmL}^{-1}$ anti den $\mathrm{MAb}$ \\
$0.588-0.692$ & 2 & $6 \mathrm{ngmL}^{-1}$ anti den MAb \\
$0.000-0.096$ & 3 & Neat Serum \\
$0.211-0.289$ & 4 & $2 \mathrm{ngmL}^{-1}$ anti den $\mathrm{MAb}$ \\
$0.951-1.078$ & 5 & $10 \mathrm{ngmL}^{-1}$ anti den $\mathrm{MAb}$ \\
$0.000-0.127$ & 6 & $10 \mathrm{ngmL}^{-1}$ SARS MAb \\
$0.473-0.535$ & 7 & $4 \mathrm{ngmL}^{-1}$ anti den MAb \\
\hline
\end{tabular}

We obtained detection limit as low as 0.4 $\mathrm{ng} / \mathrm{mL}$ (data not shown). Further optimization would offer a rapid alternative to whole virus antigen based diagnostic assays. This expression system can be exploited for other recombinant proteins as well which would be biologically functional and also in developing a dengue vaccine owing to high yield protein production at a very reasonable cost. The recombinant Env protein will be used to develop several MAbs with different specificities from immunized mice. MAbs against dengue Env is known to protect mice against dengue infection (36).

In summary the Den-1 full length Envelope protein was efficiently expressed in the E.coli system. We hope to develop several MAbs $(37,38)$ in future to develop an oligoclonal antibody cocktail based therapeutic vaccine against all the dengue virus serotypes. The full length Env protein could also be used for dengue diagnostic studies (39-45). Development of drugs inhibiting the Env mediated dengue infection can be exploited with a functional recombinant protein. In addition to this there are many targeting approaches and the development of nanocarrier vaccine have been reviewed $(46,47)$. This would be highly inexpensive procedure for the development of antigens for large-scale use in terms of therapeutics and diagnostics.

\section{Competing interests}

The authors declare that they have no competing interests.

\section{Authors' contributions}

Conceived and designed the experiments: MRS, AG, DD. performed the experiments: AG, DD and RBM. Analyzed the data: AG, DD, MRS and HHS. Contributed reagents/materials/analysis tools: MRS, HHS. Wrote the paper: AG. All authors read and approved the final manuscript.

\section{ACKNOWLEDGEMENT}

This work was supported by research grant from The Natural Sciences and Engineering Research Council of Canada (NSERC-Strategic). Thanks to Dr. Sandra Marcus for providing the French press facility, Department of Chemistry, University of 
Alberta, Edmonton, AB, Canada. Thanks to Dr. Aravinda deSilva and Dr. WMPB Wahala for providing with the anti-dengue Monoclonal antibodies, Department of Microbiology and Immunology, University of North Carolina, Chapel Hill, NC, USA

\section{REFERENCES}

1. Whitehead SS, Blaney JE, Durbin AP, Murphy BR. Prospects for a dengue virus vaccine. Nat. Rev. Microbiol. 2007; 5 : 518-528.

2. Balsitis SJ, Williams KL, Lachica R, Flores D, Kyle JL, Mehlhop E, Johnson S, Diamond MS, Beatty PR, Harris E. Lethal Antibody Enhancement of Dengue Disease in Mice Is Prevented by $\mathrm{Fc}$ Modification. PLoS Pathog. 2010; 6(2) : e1000790. doi:10.1371/journal.ppat.1000790.

3. Malabadi RB, Ganguly A, Teixera da Silva JA, Parashar A, Suresh MR, Sunwoo HH. Overview of plant-derived vaccine antigens: Dengue virus. J. Pharmac. Pharm. Sci. 2011; 14 : 400-413.

4. Men R, Wyatt L, Tokimatsu I, Arakaki S, Shameem G, Elkins R, Chanock R, Moss B, Lai CJ. Immunization of rhesus monkeys with a recombinant of modified vaccinia virus Ankara expressing a truncated envelope glycoprotein of dengue type 2 virus induced resistance to dengue type 2 virus challenge. Vaccine. 2000; 18 : 31133122.

5. Mota J, Acosta M, Argotte R, Figueroa R, Mendez A, Ramos C. Induction of protective antibodies against dengue virus by tetravalent DNA immunization of mice with domain III of the envelope protein. Vaccine. 2005; $23: 3469-3476$.

6. Putnak R, Barvir DA, Burrous JM, Dubois DR, D'Andrea VM, Hoke CH, Sadoff JC, Eckels KH. Development of a purified, inactivated, dengue-2 virus vaccine prototype in Vero cells: immunogenicity and protection in mice and rhesus monkeys. J Infect. Dis. 1996; 174 : 1176-1184.

7. Wu SF, Liao CL, Lin YL, Yeh CT, Chen LK, Huang YF, Chou HY, Huang JL, Shaio MF, Sytwu HK. Evaluation of protective efficacy and immune mechanisms of using a non-structural protein NS1 in DNA vaccine against dengue 2 virus in mice. Vaccine. 2003; $21:$ 3919-3929.

8. Chen Y, Maguire T, Marks RM. Demonstration of binding of dengue virus envelope protein to target cells. J Virol. 1996; 70 : 8765-8772.

9. Megret F, Hugnot JP, Falconar A, Gentry MK, Morens DM, Murray JM, Schlesinger JJ, Wright PJ, Young P, Van Regenmortel MH. Use of recombinant fusion proteins and monoclonal antibodies to define linear and discontinuous antigenic sites on the dengue virus envelope glycoprotein. Virology. 1992; $187:$ 480-491.
10. Chen Y, Maguire T, Hileman RE, Fromm JR, Esko JD, Linhardt RJ, Marks RM. Dengue Virus Infectivity depends on envelope protein binding to target cell heparan sulfate. Nat. Med. 1997; 3 : 866871.

11. Das D, Mongkolaungkoon S, Suresh MR. Super induction of dengue virus NS1 protein in E. coli. Protein Expr. Purif. 2009; 66 : 66-72.

12. Sambrook J, Fritsch EF, Maniatis T. Molecular Cloning: A Laboratory Manual, vol. I. $2^{\text {nd }}$ edition. Cold Spring Harbor Laboratory Press. 1989 ISBN 087969-309-6.

13. Laemmli UK. Cleavage of structural proteins during the assembly of the head of bacteriophage T4. Nature. 1970; $227: 680-685$.

14. Towbin H, Staehelin T, Gordon J. Electrophoretic transfer of proteins from polyacrylamide gels to nitrocellulose sheets: procedure and some applications. Proc. Natl. Acad. Sci. USA. 1979; 76 : 4350-4354.

15. Das D, Suresh MR. Copious production of SARS$\mathrm{CoV}$ nucleocapsid protein employing codon optimized synthetic gene. J Virol. Meth. 2006; 137 : 343-346.

16. Tsumoto K, Umetsu M, Kumagai I, Ejima D, Philo JS, Arakawa T. Role of arginine in protein refolding, solubilization, and purification. Biotechnol. Prog. 2004; 20 : 1301-1308.

17. Pattnaik P, Babu JP, Verma SK, Tak V, Rao PV. Bacterially expressed and refolded envelope protein (domain III) of dengue virus type-4 binds heparan sulfate. J Chromatogr B Analyt Technol Biomed Life Sci. 2007; 846 : 184-194.

18. Kuhn RJ, Zhang W, Rossmann MG, Pletnev SV, Corver J, Lenches E, Jones CT, Mukhopadhyay S, Chipman PR, Strauss EG, Baker TS, Strauss JH. Structure of dengue virus: implications for flavivirus organization, maturation, and fusion. Cell. 2002; 108 : 717-725.

19. Staropoli I, Frenkiel MP, Megret F, Deubel V. Affinity-purified dengue-2 virus envelope glycoprotein induces neutralizing antibodies and protective immunity in mice. Vaccine. 1997; 15 : 1946-1954.

20. Srivastava AK, Putnak JR, Warren RL, Hoke Jr CH. Mice immunized with a dengue type 2 virus $\mathrm{E}$ and NS1 fusion protein made in Escherichia coli are protected against lethal dengue virus infection. Vaccine. 1995; $13: 1251-1258$.

21. Staropoli I, Clement JM, Frenkiel MP, Hofnung M, Deubel V. Dengue virus envelope glycoprotein can be secreted from insect cells as a fusion with the maltose-binding protein. J Virol Methods. 1996; 56 : 179-189.

22. Sugrue RJ, Cui T, Xu Q, Fu J, Chan YC. The production of recombinant dengue virus $\mathrm{E}$ protein using Escherichia coli and Pichia pastoris. $J$ Virol Meth. 1997; 69 : 159-169. 
23. Das D, Gares SL, Nagata LP, Suresh MR. Evaluation of a Western Equine Encephalitis recombinant E1 protein for protective immunity and diagnostics. Antiviral Res. 2004; 64 : 85-92.

24. Zhang ZS, Yan YS, Weng YW, Huang HL, Li SQ, He S, Zhang JM. High-level expression of recombinant dengue virus type 2 envelope domain III protein and induction of neutralizing antibodies in BALB/C mice. J Virol Meth. 2007; 143 : 125131.

25. Kelly EP, Greene JJ, King AD, Innis BL. Purified dengue 2 virus envelope glycoprotein aggregates produced by baculovirus are immunogenic in mice. Vaccine. 2000; 18 : 2549-2559.

26. Lin B, Parrish CR, Murray JM, Wright PJ. Localization of a neutralizing epitope on the envelope protein of dengue virus type 2. Virology. 1994; 202: 885-890.

27. Trirawatanapong $\mathrm{T}$, Chandran $\mathrm{B}$, Putnak R, Padmanabhan R. Mapping of a region of dengue virus type-2 glycoprotein required for binding by a neutralizing monoclonal antibody. Gene. 1992; 116: 139-150.

28. Das D, Jacobs F, Feldmann H, Jones SM, Suresh MR. Differential expression of the Ebola virus GP $(1,2)$ protein and its fragments in E. coli. Protein Expr. Purif. 2004; 54: 117-125.

29. Kurucz I, Titus JA, Jost CR, Segal DM. Correct disulfide pairing and efficient refolding of detergentsolubilized single-chain $\mathrm{Fv}$ proteins from bacterial inclusion bodies. Mol. Immunol. 1995; 32: 14431452.

30. Fath S, Bauer AP, Liss M, Spriestersbach A, Maertens B, Hahn P, Ludwig C, Schafer F, Graf M, Wagner R. Multiparameter RNA and codon optimization: A standardized tool to assess and enhance autologous mammalian gene expression. PLoS ONE. 2011; 6(3) : e17596. doi:10.1371/journal.pone.0017596.

31. Jaiswal S, Khanna N, Swaminathan S. High-level expression and one-step purification of recombinant dengue virus type 2 envelope domain III protein in Escherichia coli. Protein Expr. Purif. 2004; 33 : 8091.

32. Guzman ML, Belin D, Carson MJ, Beckwith J. Tight regulation, modulation, and high-level expression by vectors containing the arabinose PBAD promoter. J Bacteriol. 1995; 177: 4121-4130.

33. Bradford MM. A rapid and sensitive method for the quantitation of microgram quantities of protein utilizing the principle of protein-dye binding. Anal Biochem. 1976; 72: 248-254.

34. Kanai R, Kar K, Anthony K, Gould LH, Ledizet M, Fikrig E, Marasco W, Koski RA, Modis Y. Crystal Structure of west nile glycoprotein reveals viral surface epitopes. Amer Soc Micro. 2006; 80 : 11000-11008.
35. Nayak V, Dessau M, Kucera MK, Anthony K, Ledizet M, Modis Y. Crystal structure of dengue virus type 1 envelope protein in the postfusion conformation and its implications for membrane fusion. J Virol. 2009; 83 : 4338-4344.

36. Kaufman BM, Summers PL, Dubois DR, Eckels KH. Monoclonal antibodies against dengue 2 virus E-glycoprotein protect mice against lethal dengue infection. Am J Trop Med Hyg. 1987; 36 : 427-434.

37. Suresh MR, Cuello AC, Milstein C. Advantages of bispecific hybridomas in one-step immunocytochemistry and immunoassays. Proc. Natl. Acad. Sci. U.S.A. 1986a; 83, 7989-7993.

38. Suresh MR, Cuello AC, Milstein C. Bispecific monoclonal antibodies from hybrid hybridomas. Methods Enzymol. 1986b; 121, 210-228.

39. Holbrook MR Shope RE, Barrett AD. Use of recombinant $\mathrm{E}$ protein domain III-based enzymelinked immunosorbent assays for differentiation of tick-borne encephalitis serocomplex flaviviruses from mosquito-borne flaviviruses. J. Clin. Microbiol. 2004; 42(9) : 4101-4110.

40. Bisht H, Chugh DA, Swaminathan S, Khanna N. Expression and purification of Dengue virus type 2 envelope protein as a fusion with hepatitis B surface antigen in Pichia pastoris. Protein Expr Purif. 2001; $23: 84-96$.

41. Burleson FG, Chambers TM, Wiedbrauk DL. Virology: A Laboratory Manual. Academic Press (New York) 1992.

42. Ganguly A, Malabadi RB, Lobenberg R, Suresh MR, Sunwoo HH. A mini-review of dengue vaccine development. Res in Pharm. 2013a; 3(2):18-25.

43. Ganguly A, Malabadi RB, Lobenberg R, Suresh MR, Sunwoo HH. Dengue diagnostics: Current scenario. Res in Biotech. 2013b; 4(2):19-25.

44. Malabadi RB, Parashar A, Ganguly A, Suresh MR. Expression of Dengue virus envelope protein in a different plant system. Faculty Research and Development day, Faculty of Pharmacy and Pharmaceutical Sciences, University of Alberta, Edmonton, Canada, 19th November 2010. Pp. 31.

45. Malabadi RB, Ganguly A, Hoon HH, Suresh MR. Role of bispecific monoclonal antibodies in immunodiagnostic assays. Res in Pharm. 2012; 2(3): 08-14.

46. Khan SR, Ganguly A, Malabadi RB, Sunwoo HH, Parashar A, Teixeira da Silva JA, Suresh MR. Targeting strategies and nanocarriers in vaccines and therapeutics. Res in Biotech. 2011; 2(6), 08-20.

47. Khan SR, Ganguly A, Malabadi RB, Sunwoo HH, Suresh MR. Gene delivery system: A developing arena of study for new era of medicine. Recent Patents on DNA \& Gene Sequences. 2012; 6(1): 2-9 (8).

48. The Tuberculosis Trial Consortium (2002) Rifapentine and isoniazid once a week versus rifampicin and isoniazid twice a week for treatment 
of drug-susceptible pulmonary tuberculosis in HIVnegative patients: a randomised clinical trial. Lancet 360: 528-34. doi: 10.1016/S0140-6736(02)09742-8

49. Sarkar S, Tang XL, Das, D, Spencer J, Lowary TL, Suresh MR. A Bispecific Antibody Based Assay Shows Potential for Detecting Tuberculosis in Resource Constrained Laboratory Settings. Plos One. 2012: 7(2): e32340. doi:10.1371/journal.pone.0032340

50. Ganguly A, Malabadi RB, Loebenberg R, Suresh MR, Sunwoo HH. Development of an ultrasensitive hetero-sandwich ELISA assay based on bispecific monoclonal antibody for the detection of dengue NS1 protein. J. Pharm. Res. (2013c) 7(5): 374-380 